\title{
Analysis of Different Backyard Poultry Breeds in Mid-Central Table Land Zone of Odisha
}

\author{
B. Satpathy ${ }^{1 *}$, B. Mohanty ${ }^{2}$, R. B. Nayak $^{2}$ and M. Behera ${ }^{1}$ \\ ${ }^{1}$ Krishi Vigyan Kendra, Angul, AT- Panchamahala, P.O.- Hulurisingha, \\ Dist. - Angul, PIN- 759132, India \\ ${ }^{2}$ Krishi Vigyan Kendra, Dhenkanal, AT/P.O.- Mahisapat, \\ Dist.- Dhenkanal, PIN- 759013, Odisha, India \\ *Corresponding author
}

\section{A B S T R A C T}

\section{Keywords}

Body weight, Poultry breeds, Egg production,

Mortality, Net return

Article Info

Accepted:

10 July 2020

Available Online:

10 August 2020
A study was conducted in the Mid-Central Table Land zone of Odisha involving Angul and Dhenkanal districts to assess the performance of different backyard poultry breeds which includes existing non-descript desi breeds and improved breeds like Vanaraja, Pallishree, Aseel and Kadaknath. Ten farmers from both the districts were covered under the study. Parameters like mean body weight at different ages, age at first egg, annual egg production and mortality rate etc. along with economic parameters were studied apart from qualitative parameters like consumer preference, price offered. The result indicated that Vanaraja showed better annual egg production and Pallishree gained better body weight at $20^{\text {th }}$ week. The economics showed highest net return in case of Kadaknath and highest BC ratio in case of desi birds. Even though the two strains Vanaraja and Pallishree performed well with respect to meat and egg production, Aseel is the most preferred breed for backyard condition by the farmers due its external appearance, consumer preference, self defence from predators followed by Kadaknath which are next to Desi breeds.

\section{Introduction}

Backyard poultry is a system of keeping poultry birds in free range backyard condition being practiced in rural India since time immemorial. It involves low or no cost and has been proved to be sustainable over so many years being a type of organic farming with environment friendly approach. It plays a vital role in rural economy ensuring food and livelihoods security. It also ensures nutritional security in rural ecosystem as major portion of egg and meat production from backyard poultry are mostly consumed at household level which supplies valuable animal protein to them. This enterprise provides 
supplementary income in shortest possible time and requires less capital investment. Mostly the rural farmers keep desi nondescript birds. Advantage with these birds is that they have better adaptability to local condition as they demand least infrastructure, protect themselves from predators and are less prone to diseases. Due to these characteristics, they are widely accepted by rural poor.

In our country backyard poultry is mostly characterised by a small flock size consisting 10-15 desi birds maintained in extensive system i.e. by indigenous shelter, little supplementary feeding mostly from house hold waste, scavenging system and natural hatching of chicks, eggs produced are usually for captive use or limited trade within the village. This is a major income generating activity of rural women. It is noticed that desi bird rearing in backyard condition is very much close to tribal families more specifically tribal women.

In spite of so many good traits, poor egg and meat productivity are the major concerns of desi non-descript birds. Intensive or commercial poultry cannot sustain in rural households being prone to diseases in conditions where there is shortage of feed and fodder. So, it is desirable to promote improved breeds suitable for backyard condition which has better egg and meat productivity. Also emphasis should be given for selection of breed which is less prone to disease, less mortality rate, better consumer preference, can protect itself from predators etc.

Keeping in view of the above facts, breeds like Vanaraja, Chhabro, Pallishree, Kaveri Aseel, Kadaknath etc. are being promoted through different mandatory activities by Krishi Vigyan Kendras, ARD Deptt., development organisations and under many schemes by Govt.

\section{Materials and Methods}

The present study was conducted in MidCentral Table Land zone of Odisha involving Angul and Dhenkanal districts during 201920.In each district 10 farmers were selected, training was imparted to the farmers on standard package of practices for backyard poultry by Krishi Vigyan Kendras. All the selected farmers were provided with 10 number of day old chicks from Vanaraja, Pallishree, Aseel and Kadaknath breeds. Scientist of Krishi Vigyan Kendra conducted regular field visits to note production parameters and farmers' feedback apart from providing technological support. Parameters like Mortality percentage (0-12 weeks), body weight at $12^{\text {th }}$ and $20^{\text {th }}$ week $(\mathrm{Kg})$, age at first egg and annual egg production etc. were recorded and the data was analyzed to derive conclusive statements from the study.

\section{Results and Discussion}

The production parameters of the improved breeds along with desi non-descript breed have been recorded and presented in Table. 1

\section{Mortality Percentage (0-12Weeks)}

In case of desi breeds mortality rate was found to be minimum $(2.47 \%)$ where as in case of improved breeds it was more. The reason for low mortality in desi breed could be due to its adaptability to the local environment and proper brooding by their mother. In case of Aseel and Kadaknath breeds the mortality rates are $4.67 \%$ and $5.05 \%$ respectively which are less than Vanaraja (6.47\%) and Pallishree (5.77\%). The cause could be the presence of local strains in these breeds.

\section{Body weight at $12^{\text {th }}$ and $20^{\text {th }}$ week}

The body weight at $12^{\text {th }}$ and $20^{\text {th }}$ week is a factor which determines the meat production 
and hence income generated out of that. Comparative analysis reveals that Pallishree breed showed better meat yield at $12^{\text {th }}$ and $20^{\text {th }}$ week (1.85 and $\left.2.94 \mathrm{~kg}\right)$ than any other breeds followed by Vanaraja (1.72 and 2.52 $\mathrm{kg})$. The desi breed in case of farmers' practice showed minimum meat yield at $12^{\text {th }}$ and $20^{\text {th }}$ week $(0.74$ and $1.05 \mathrm{~kg})$.

\section{Annual average egg production}

Egg production is one of the important factors which determines the success of back yard poultry. The egg production not only contributes to the household income but it contributes substantially to the nutritional supplementation of the rural poor. Maximum egg production was observed in case of Vanaraja (130) followed by Kadaknath (110). In case of desi breed egg production was recorded to be the minimum (70).

\section{Age at first egg}

In all the breeds age at first egg was found to be after six months and at in case of Vanaraja it was observed to be minimum (156 days).

Economic analysis was conducted taking both meat and egg production as well as cost of production into account. The economic indicators for all the breeds as per observed data is presented in Table 2.

Net income is found to be maximum (Rs. 1025 / bird) in case of Kadaknath as its meat is sold at a better price (@ Rs. 300/- per kg live bird) than Vanaraja and Pallishree (both @ Rs. 200/- per kg live bird). Next to Kadaknath, net income is found to be higher in case of Desi breed (Rs. 905 / bird) which is very much nearer to Aseel (Rs. 900 / bird). Benefit - cost ratio is found to be maximum (3.83) in case of desi bird as the cost of production is minimum. Though all the $\mathrm{BC}$ ratio values are more than 3 and values for Aseel, Vanaraja and Pallishree are very close, value for Kadaknath is 3.56 which comes next to Desi bird.

\section{Farmers' feedback}

Farmers feedback formed a major component of the study. Feedback was collected for all the breeds and some interesting facts came out which may be considered while promoting the backyard poultry breeds in rural ecosystem. Some of the feedbacks which are necessary to be mentioned here are presented below.

Table.1 Performance of backyard poultry breeds:

\begin{tabular}{|c|c|c|c|c|c|c|}
\hline $\begin{array}{c}\text { S. } \\
\text { No }\end{array}$ & Particulars & $\begin{array}{c}\text { Mortality } \\
\text { during 0- } \\
\text { 12 weeks } \\
\text { (\%) }\end{array}$ & $\begin{array}{c}\text { Body } \\
\text { weight at } \\
\mathbf{1 2}^{\text {th }} \text { week } \\
\text { (kg) }\end{array}$ & $\begin{array}{c}\text { Body } \\
\text { weight at } \\
\mathbf{2 0}^{\text {th }} \text { week } \\
\text { (kg) }\end{array}$ & $\begin{array}{c}\text { Average } \\
\text { age at egg } \\
\text { laying } \\
\text { (days) }\end{array}$ & $\begin{array}{c}\text { Annual } \\
\text { average egg } \\
\text { production } \\
\text { (no.) }\end{array}$ \\
\hline $\mathbf{1}$ & FP & 2.47 & 0.74 & 1.05 & 194 & 70 \\
\hline $\mathbf{2}$ & Vanaraja & 6.47 & 1.72 & 2.52 & 156 & 130 \\
\hline $\mathbf{3}$ & Pallishree & 5.77 & 1.85 & 2.94 & 162 & 110 \\
\hline $\mathbf{4}$ & Aseel & 4.67 & 0.95 & 1.35 & 180 & 95 \\
\hline $\mathbf{5}$ & Kadaknath & 5.05 & 1.25 & 1.95 & 185 & 105 \\
\hline & SEM & 0.269 & 0.03 & 0.269 & 2.197 & 1.933 \\
\hline & CD & 0.828 & 0.091 & 0.829 & 6.769 & 5.955 \\
\hline
\end{tabular}

Economic analysis was conducted taking both meat and egg production as well as cost of production into account. The economic indicators for all the breeds as per observed data is presented in Table 2. 
Table.2 Economic Performance of backyard poultry breeds:

\begin{tabular}{|c|c|c|c|c|}
\hline S. No & Particulars & $\begin{array}{c}\text { Gross Income } \\
\text { (Rs. / bird) }\end{array}$ & $\begin{array}{c}\text { Net Income } \\
\text { (Rs. / bird) }\end{array}$ & BC Ratio \\
\hline $\mathbf{1}$ & FP & 1225 & 905 & 3.83 \\
\hline $\mathbf{2}$ & Vanaraja & 1284 & 884 & 3.21 \\
\hline $\mathbf{3}$ & Pallishree & 1248 & 848 & 3.12 \\
\hline $\mathbf{4}$ & Aseel & 1300 & 900 & 3.25 \\
\hline $\mathbf{5}$ & Kadaknath & 1425 & 1025 & 3.56 \\
\hline
\end{tabular}

The dual purpose breeds are better to be sold within 3 to 4 months, i.e. better to use for meat purpose. For all the improved breeds, availability of day old chicks as well as brooded chicks is a problem for which the rural farmers discontinue to keep these breeds after a batch is sold. To promote these breeds both hatching and brooding facility should be promoted so as to make the effort sustainable. In case of desi breeds, the farmers get chicks naturally with brooding of eggs by mother bird, hence have been proven to be sustainable and successful. The demand for meat of desi birds, their self-defence mechanism against predators are factors responsible for more level of acceptance of desi breed amongst rural poor. The breed Aseel is able to defend itself from predators, demand for meat of both Aseel and Kadaknath are also at par with desi breed, hence more acceptable amongst the improved breeds.

In conclusion, preference of farmers, consumers' preference, self defence of birds against predators are few factors which need to be considered for selection of backyard poultry breeds to be promoted in rural areas. Promotion of hatching and brooding facility in rural areas should go hand in hand as eggs in case of improved breeds are not being hatched and brooded by their mothers. It is to be kept in mind that farmers have a great inclination towards desi breeds due to many obvious factors, the farmers' economics should be properly understood and any breed which are very close to their choice should be thought to be promoted.

\section{References}

Pathak PK and Nath BG. Rural Poultry Farming with Improved Breed of Backyard Chicken. Journal of World's Poultry Research, 2013;3(1): 24-273.

Chakravarthy PV, Mohan B and SenthilkumarK. Performance of CARI Nirbheek (Aseel Cross) birds reared under intensive and semi intensive system in Namakkal District. Indian Veterinary Journal, 2014; 91(11):85-87.

Patra, J and Singh DV (2016). Backyard poultry farming, a suitable Intervention for Tribal people for their livelihood support and Nutritional security. International Journal of Humanities and Social Science Innovation, 2016; 5(6):22-26

Reetha TL, Rajeswar JJ, Harikrishnan TJ, Sukumar K, Srinivasan P, Kirubakaran JJ (2016) Studies on the effectiveness of oral pellet vaccine in improving egg production and egg quality in desi chicken. Veterinary World, 2016; 9(8): 900-903.

Karuna sree E, Vijaya Nirmala T and Reddy RVSK. Comparative performance of different varieties of chicken under backyard system of rearing in tribal and rural areas of West Godavari district, A.P. International Journal of Science, Environment and Technology, 2017; 
6(2) : $1100-1104$

Nandi S, Sharma K, Pawan K and Nandi D. Poultry farming, A rapidly growing profitable business. Poultry Line, (2007); 7(12): 19-20.

Nath BG, Toppo S, Chandra R, Chatlod LR and Mohanty AK. Level of adoption and constraints of scientific backyard poultry rearing practices in rural tribal areas of Sikkim. Indian Journal of Animal and Feed Research, (2012); 2(2):133-138.

Panda AK, Raju MVLN and Ram Rao SV. Poultry production in India : Opportunities and challenges Ahead.
Poultry Line, (2008); 8(1): 11-14.

Sarma M, Islam R, Borah MK, Sharma P, Mahanta JD, Kalita $\mathrm{N}$ and Bhattacharyya BN. Comparative performance of Vanaraja, Srinidhi and Desi chicken under traditional system among tribal community of Assam.Indian Journal of Animal Research, 2017;B-3391:1-3

Sasidhar PVK, Majumdar S, Chander MA and Tripathi $H$. Factors influencing adoption of backyard poultry by farmers in India. World Poultry Science Journal, (2008); 2:315.

\section{How to cite this article:}

Satpathy, B., B. Mohanty, R. B. Nayak and Behera, M. 2020. Analysis of Different Backyard Poultry Breeds in Mid-Central Table Land Zone of Odisha. Int.J.Curr.Microbiol.App.Sci. 9(08): 306-311. doi: https://doi.org/10.20546/ijcmas.2020.908.036 